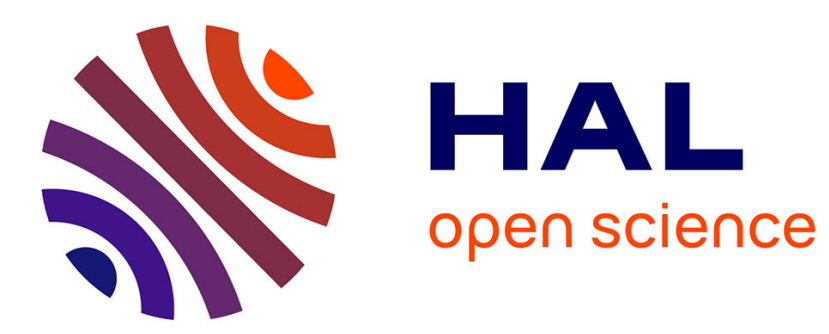

\title{
A Functionalized, Deep Cavitand Catalyzes the Aminolysis of a Choline Derivative
}

\author{
Arnaud Gissot, Julius Rebek
}

\section{To cite this version:}

Arnaud Gissot, Julius Rebek. A Functionalized, Deep Cavitand Catalyzes the Aminolysis of a Choline Derivative. Journal of the American Chemical Society, 2004, 126 (24), pp.7424-7425. $10.1021 / \mathrm{ja049074r}$. hal-02491812

\section{HAL Id: hal-02491812 \\ https://hal.science/hal-02491812}

Submitted on 26 Feb 2020

HAL is a multi-disciplinary open access archive for the deposit and dissemination of scientific research documents, whether they are published or not. The documents may come from teaching and research institutions in France or abroad, or from public or private research centers.
L'archive ouverte pluridisciplinaire HAL, est destinée au dépôt et à la diffusion de documents scientifiques de niveau recherche, publiés ou non, émanant des établissements d'enseignement et de recherche français ou étrangers, des laboratoires publics ou privés. 


\section{A Functionalized, Deep Cavitand Catalyzes the Aminolysis of a Choline Derivative}

Arnaud Gissot and Julius Rebek, Jr.*

The Skaggs Institute for Chemical Biology and The Department of Chemistry, The Scripps Research Institute, 10550 North Torrey Pines Road, La Jolla, California 92037

E-mail: jrebek@scripps.edu

Cavitands are bowl-shaped structures widely used in studies of molecular recognition. ${ }^{1}$ Most are derived from condensation of resorcinol with aldehydes through Högberg' $\mathrm{s}^{2}$ efficient synthesis. The cyclic tetramers (resorcinarenes) have a history as hosts, ${ }^{3}$ but their greater potential as modules for more elaborate structures carcerands, ${ }^{4}$ velcrands, ${ }^{5}$ and deeper cavitands ${ }^{6}$ was recognized by $\mathrm{Cram}^{7}$ and Dalcanale. ${ }^{8}$ We found a way to stabilize the vase-like conformation ${ }^{9}$ and, subsequently, a means to monofunctionalize its rim. ${ }^{10}$ The result is a host structure that more or less surrounds a guest and presents it with a well-positioned functional group. The principles of molecular recognition-based catalysis are well known and have been applied in the context of crown ethers, ${ }^{11}$ cyclodextrins, ${ }^{12}$ cyclophanes, ${ }^{13}$ and other synthetic receptors, ${ }^{14}$ but the combination of inwardly directed functional group and cavitand receptor is unique. Here we explore its consequences in catalysis. Acetylcholine and other guests bearing a trimethylammonium knob bind strongly to deep cavitands in organic solvents. ${ }^{15}$ This recognition was used to position reactive centers on a guest near functional groups known to catalyze aminolysis reactions attached to the host. Specifically, pyridone is a known bifunctional catalyst for the breakdown of tetrahedral intermediates. ${ }^{16}$ The aminolysis of active esters in aprotic organic solvents proceeds through the rapid, reversible formation of a tetrahedral intermediate followed by its rate-determining breakdown to products. ${ }^{17}$ The mechanism of the catalysis by pyridone is depicted in Scheme 1. The tetrahedral intermediate of the reaction can form two $\mathrm{H}$-bonds to the pyridone of $\mathbf{1}$, while the ester reactant and amide product can form only one. Accordingly, the higher-energy species along the reaction coordinate are more complementary to $\mathbf{1}$, a prerequisite for minimizing product inhibition and encouraging turnover.
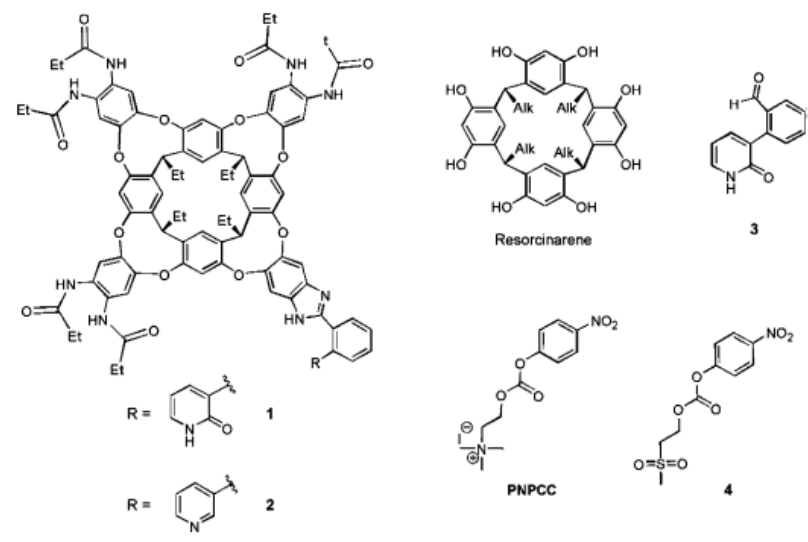

The cavitand 1 was synthesized through condensation of the known hexaamide diamino cavitand ${ }^{18}$ with the aldehyde 3 in $47 \%$ isolated yield. A calculated structure of $\mathbf{1}$ (Maestro, Amber force field) with the tetrahedral intermediate does allow the desired $\mathrm{H}$ - bonds necessary for the catalytic action and shows some rotational freedom of the pyridone with respect to the rim of the cavitand. This provides some flexibility to reach the optimum stabilization of the intermediate and, in turn, to facilitate its breakdown to products (Figure 1).

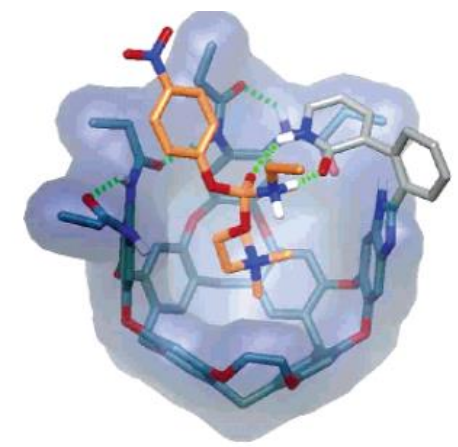

Figure 1. Energy-minimized structure of the cavitand 1 with the tetrahedral intermediate formed from PNPCC and propylamine. One of the four walls and some atoms have been omitted for clarity.

Scheme 1. Pyridone-Catalyzed Aminolysis of Esters

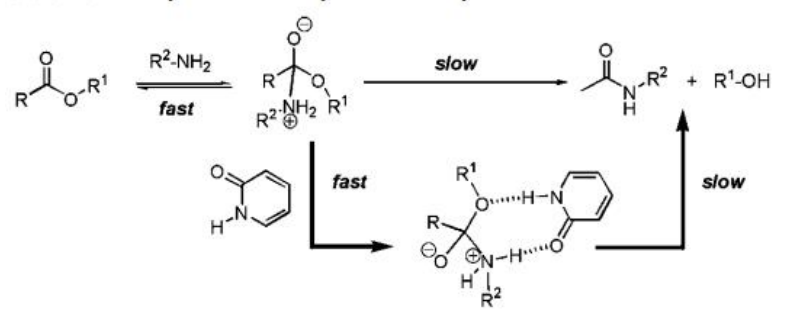

The modeling also shows the rotation of the pyridone into and out of the cavity to be restricted by steric clashes with the neighboring amides. ${ }^{1} \mathrm{H}$ NOE experiments at $213 \mathrm{~K}$ show clear chemical exchange between the two atropisomers of $2:{ }^{19}$ the required introverted and the unreactive extraverted conformations. $^{20}$ Integration of the cross-peaks gives an energetic barrier of $12.7 \mathrm{kcal}_{\text {. }} \mathrm{mol}^{-1}$ for the in/out interconversion, a barrier that allows rapid interconversion at room temperature. For the substrate, we used the same $p$-nitrophenyl choline carbonate (PNPCC) that has been used as an analogue of acetyl choline. ${ }^{21}$ Its aminolysis can be conveniently monitored using UV detection of the released $p$-nitrophenolate. Initial runs showed that $\mathbf{1}$ is a potent catalyst for this reaction (Table 1). In contrast, model pyridine cavitand 2, 2-pyridone itself, or a mixture of both (entries 3,4 , and 5 , respectively) proved ineffective in catalyzing the reaction. The absence of catalysis in the presence of the free catalytic motif 2-pyridone (entries 4 and 5) was somewhat puzzling. Yet, 2-pyridone is a known catalyst for the aminolysis of esters, not carbonates. In fact, the tetrahedral intermediate formed after the attack of the amine onto the carbonate is less 
likely to form and more reactive than the one obtained from corresponding esters. ${ }^{17 \mathrm{~b}}$ Consequently, the intermediate may either undergo the uncatalyzed reaction or revert to the starting amine and PNPCC before the pyridone can form the catalytically active complex (Scheme 1), unless the pyridone is in close vicinity of the intermediate as in $\mathbf{1}$.

Table 1. Aminolysis of PNPCC in the Presence of Catalysts

\begin{tabular}{|c|c|c|c|c|}
\hline entry & catalyst & mole $\%$ & $v_{0}\left(\mu \mathrm{M} \cdot \mathrm{min}^{-1}\right)^{b}$ & $v_{0}$ cat $/ v_{0}$ uncal. \\
\hline 1 & - & & 1.6 & 1 \\
\hline 2 & 1 & 10 & 3.5 & 2.2 \\
\hline 3 & 2 & 10 & 1.6 & 1 \\
\hline 4 & 2-pyridone & 10 & 1.6 & 1 \\
\hline 5 & $2+2$-pyridone & 10 & 1.6 & 1 \\
\hline 6 & 1 & 17 & 6.0 & 3.7 \\
\hline 7 & 1 & 87 & 16.5 & 10.3 \\
\hline 8 & 1 & 193 & 25.0 & 15.6 \\
\hline 9 & 2-pyridone & 193 & 1.8 & 1.1 \\
\hline
\end{tabular}

${ }^{a}$ Conditions: $40 \mu \mathrm{M}$ PNPCC, $40 \mu \mathrm{M}$ propylamine, $20 \mathrm{mM}$ Hünig's base, $0.5 \mathrm{mM}$ TFA in $\mathrm{CH}_{2} \mathrm{Cl}_{2} / \mathrm{CH}_{3} \mathrm{CN}, 99 / 1$, room temperature. ${ }^{b}$ In the absence of propylamine (bufferolysis) $v_{0}=0.4 \mu \mathrm{M} \cdot \mathrm{min}^{-1}$.

These results suggest a synergy between the recognition of the ammonium of PNPCC in the cavity of 1 and the catalytic activity brought to bear by the pyridone located on the rim of 1 . The quantity of catalyst has a marked effect on the initial rates of the reaction (entries 2 and 6-9). ${ }^{22}$ The reaction is accelerated up to ca. 16 times in the presence of 2 equiv of catalyst (entry 8), compared with the modest (10\%) acceleration observed in the presence of 2 equiv of pyridone under the same conditions (entry 9). ${ }^{23}$ Given the very low binding constant of PNPCC to $\mathbf{1}$ in $\mathrm{CD}_{2} \mathrm{Cl}_{2} / \mathrm{CD}_{3} \mathrm{CN}\left(\mathrm{Ka}=17 \mathrm{M}^{-1}\right),{ }^{24}$ this translates into rate acceleration of ca. 6000 ( 0.17 equiv of 1 ) when comparing the reaction in the bulk and the reaction inside 1 . The weak binding affinity of PNPCC to 1 was anticipated and desired to provide catalytic turnover, and turnover does clearly take place. In fact, after $50 \%$ conversion, the aminolysis rate of PNPCC in the presence of 10 mol \% of 1 remains higher than the initial rate of the reaction in the absence of catalyst. As suggested by the energy-minimized structure (Figure 1), bulky primary amines such as tritylamine should experience substantial steric hindrance in this reaction within (and outside) the cavitand. Indeed, even though the uncatalyzed reaction with tritylamine is 2.5 times slower, no catalysis is observed in the presence of $10 \mathrm{~mol} \%$ of 1 . Similarly, no catalysis is observed using the carbonate $\mathbf{4}$ as substrate. This result is expected since the sulfone function of $\mathbf{4}$ has no affinity for the cavity of $\mathbf{1}$. Accordingly, we conclude that the ammonium of PNPCC and of its subsequent tetrahedral intermediate must be recognized by the pocket of $\mathbf{1}$ to experience catalysis in the aminolysis reaction. The pyridone is poised to aid the collapse of the tetrahedral intermediate formed from PNPCC. In conclusion, the combination of a well-defined binding pocket and wellpositioned functional groups creates a unique environment with catalytic properties and gives high substrate specificity in this and alkylation reactions. ${ }^{25}$

Acknowledgment. We are grateful to the Skaggs Research Foundation and the NIH (GM 27932) for financial support. A.G. is a Skaggs Postdoctoral Fellow. We thank Prof. Javier de Mendoza,
Madrid, Spain, for providing us with a procedure for the synthesis of PNPCC.

Supporting Information Available: Kinetics of PNPCC aminolysis; synthetic procedures and descriptions of compounds $\mathbf{1}, \mathbf{2}, \mathbf{3}$, and PNPCC; ${ }^{1} \mathrm{H}$ NOE spectrum of 2 at $213 \mathrm{~K}$.

\section{References}

(1) Cram, D. J. Science 1983, 219, 1177-1183.

(2) (a) Högberg, A. G. S. J. Am. Chem. Soc. 1980, 102, 6046-6050. (b) Högberg, A. G. S. J. Org. Chem. 1980, 45, 4498-4500.

(3) (a) Kikuchi, Y.; Kato, Y.; Tanaka, Y.; Toi, H.; Aoyama, Y. J. Am. Chem. Soc. 1991 113, 1349-1354. (b) Kobayashi, K.; Asakawa, Y.; Kikuchi, Y.; Toi, H.; Aoyama, Y. J. Am. Chem. Soc. 1993, 115, 2648-2654.

(4) Reviews: (a) Jasat, A.; Sherman, J. C. Chem. ReV. 1999, 99, 931-967. (b) Timmerman, P.; Verboom, W.; Reinhoudt, D. N. Tetrahedron 1996, 52, 26632704.

(5) (a) Moran, J. R.; Ericson, J. L.; Dalcanale, E.; Bryant, J. A.; Knobler, C. B.; Cram, D. J. J. Am. Chem. Soc. 1991, 113, 5707-5714. (b) Cram, D. J.; Choi, H.-J.; Bryant, J. A.; Knobler, C. B. J. Am. Chem. Soc. 1992, 114, 7748-7765.

(6) Rudkevich, D. M.; Rebek, J., Jr. Eur. J. Org. Chem. 1999, 1991.

(7) (a) Moran, J. R.; Karbach, S.; Cram, D. J. J. Am. Chem. Soc. 1982, 104, 5826. (b) Cram, D. J.; Karbach, S.; Kim, H.-E.; Knobler, C. B.; Maverick, E. F.; Ericson, J. L.; Helgeson, R. C. J. Am. Chem. Soc. 1988, 110, 2229.

(8) (a) Dalcanale, E.; Soncini, P.; Bacchilega, G.; Ugozzoli, F. J. Chem. Soc., Chem. Commun. 1989, 500-502. (b) Soncini, P.; Bonsignore, S.; Dalcanale, E.; Ugozzoli, F. J. Org. Chem. 1992, 57, 4608-4612.

(9) (a) Rudkevich, D. M.; Hilmersson, G.; Rebek, J., Jr. J. Am. Chem. Soc. 1997, 119, 9911-9912. (b) Rudkevich, D. M.; Rebek, J., Jr. Eur. J. Org. Chem. 1999, 19912005.

(10) Renslo, A. R.; Rebek, J., Jr. Angew. Chem., Int. Ed. 2000, 39, 3281- 3283.

(11) (a) Cram, D. J.; Sogah, G. D. Y. J. Chem. Soc., Chem. Commun. 1981, 625-628. (b) Lehn, J.-M.; Ball, P. The New Chemistry; Cambridge University Press: 2000; Chapter 12, pp 300-351.

(12) (a) Breslow, R.; Schmuck, C. J. Am. Chem. Soc. 1996, 118, 6601-6605. (b) Yang, J.; Gabriele, B.; Belvedere, S.; Huang, Y.; Breslow, R. J. Org. Chem. 2002, 67, 5057-5067.

(13) (a) Mattei, P.; Diederich, F. HelN. Chim. Acta 1997, 80, 1555-1588. (b) Habicher, T.; Diederich, F.; Gramlich, V. Helv. Chim. Acta 1999, 82, 1066-1095.

(14) (a) Tecilla, P.; Chang, S. K.; Hamilton, A. D. J. Am. Chem. Soc. 1990, 112, 95869590. (b) Kang, J.; Rebek, J., Jr. Nature 1997, 385, 50-52. (c) Chen, J.; Korner, S.; Craig, S. L.; Rudkevich, D. M.; Rebek, J., Jr. Nature 2002, 415, 385-386.

(15) Atwood, J. L.; Szumna, A. Chem. Commun. 2003, 940-941; Hof, F.; Trembleau, L.; Ullrich, E. C.; Rebek, J., Jr. Angew. Chem., Int. Ed. 2003, 42, 3150-3153.

(16) Swain, C. G.; Brown, J. F., Jr. J. Am. Chem. Soc. 1952, 71, 2538-2543.

(17) (a) Su, C.-W.; Watson, J. W. J. Am. Chem. Soc. 1974, 96, 1854-1857. (b) Castro, E. A.; Cubillos, M.; Santos, J. G. J. Org. Chem. 2001, 66, 6000-6003.

(18) Renslo, A. R.; Tucci, F. C.; Rudkevich, D. M.; Rebek, J., Jr. J. Am. Chem. Soc. 2000, $122,4573-4582$.

(19) This experiment was carried out on $\mathbf{2}$ and not $\mathbf{1}$ as the appearance of two different species at cold temperature with 1 could result from the dimerization of the pyridone and not from the two atropisomers.

(20) See Supporting Information.

(21) Cuevas, F.; Di Stefano, S.; Magrans, J. O.; Prados, P.; Mandolini, L.; de Mendoza, J. Chemistry 2000, 6, 3228-3234.

(22) The (un)catalyzed aminolysis of PNPCC is fast even in the presence of only one equivalent of propylamine relative to the carbonate. This precludes the use of pseudo-first-order conditions necessary to determine the rate constant of the reaction.

(23) The pyridone is known to readily self-dimerize in aprotic solvents. Yet, under the very dilute conditions used in our study, the dimerization alone cannot account for the lower catalytic activity of the pyridone over 1 . For instance, it was found that $37 \%$ of the pyridone exists as a dimer in chloroform for an initia concentration of $2 \mathrm{mM}$ (as compared to $0.04 \mathrm{mM}$ in our case), see: Beak, P.; Covington, J. B.; Smith, S. G.; White, J. M.; Zeigler, J. M. J. Org. Chem. 1980, 45, 1354-1362.

(24) The very low solubility of PNPCC in a mixture of $C D C l 3$ and $C D 3 C N$ precludes the accurate determination of the binding constant.

(25) Purse, B. W.; Ballester, P.; Rebek, J., Jr. J. Am. Chem. Soc. 2003, 125, $14682-$ 14683. 